\title{
Analysis of the Case of Divorce and Its Settlement in the Religious Court of Palu City
}

\author{
Rinalti Rinalti ${ }^{*}$, Syahabuddin Syahabuddin², Ermawati Ermawati ${ }^{3}$ \\ 1 Islamic Law Department, Postgraduate, Institut Agama Islam Negeri Palu \\ 2 Islamic Law Department, Postgraduate, Institut Agama Islam Negeri Palu \\ ${ }^{3}$ Faculti of Islamic Economic and Business, Institut Agama Islam Negeri Palu
}

\begin{abstract}
This paper discusses the cases of divorce and its settlement in the Religious Court of Palu. This study applied qualitative method with the data collection techniques that include observation, interview and written document. Data analysis was carried out through data reduction, presentation, verification and conclusion drawing. The result shows that the divorce proceedings handled by the Religious Court of Palu includes the applicants filed for divorce applications to the Religious Courts. Then, the Religious Courts make a number of lawsuit or application for divorce and file a summons. Furthermore, the panel of judges appointed a mediator to mediate between the litigating husband and wife. Conducting the first hearing with the agenda of reading the suit. The second hearing, listening to the response of the respondent or the defendant then delaying the decision. Listen to the testimonies of witnesses from each party. The panel of judges gives a decision on the case submitted and invites the respondent or the defendant to submit an appeal. The causes of divorce are adultery factors, drunkenness, drug consumption, gambling, leaving partner, imprisoned, polygamy, domestic violence. The majority couses of divorces are domestic violents and leaning parteners.
\end{abstract}

\section{ARTICLE \\ INFORMATION}

Keywords:

Divorce, cause of divorce, marriege, religious court. 


\section{Introduction}

The purpose of marriage according to Islam is to fulfill the instructions of religion in order to build a harmonious and happy family. Harmonious life means the creation of physical and spiritual calm that leads to happiness, that is, love between family members.

One of the principles of marriage in Islam is eternity. Therefore, Islam forbids marriages whose purpose is for a while, just to let go of lust just like temporary marriage (mut'ah), marriage of muhallil, and so on. ${ }^{1}$

According to Widodo, marriage is "living together between a man and a woman who fulfill certain conditions" 2 . Maturity in physical and spiritual aspect in marriage is the basis for achieving the goals of marriage. However, there are still many members of the community, who do not pay attention to it.

This is due to environmental influences and social development. Marriage is carried out based on the consent of the prospective bride and groom without coercion from the other party. This is for the happiness in the marriage. Everything that will be carried out needs to be planned first in order to produce good results, as well as family life (marriage).

In addition, the purpose of marriage is often not achieved in accordance with the ideals that are

${ }^{1}$ Kamal Mukhtar, Asas-Asas Hukum Islam Tentang Perkawinan, $3^{\text {rd }}$ Edition (Jakarta: Bulan Bintang, 1993), 144.

${ }^{2}$ Widodo, Faktor-faktor Serta Alasan yang Menyebabkan Tingginya Angka Cerai Gugat, Jurnal Hukum, Universitas Surakarta, 2013, 2. dreamed of, resulting from the emergence of tensions to the hostility, so that the integrity of the household can not be maintained anymore. Therefore, to maintain marriage, preparation is required from the bride and groom both physically and mentally, so that they easily adjust to achieve the goals that are dreamed of in a marriage. Another goal of marriage in Islam is to form a family and give birth to descendants, and prevent adultery, so as to create peace and peace of mind for both parties in the family and community. ${ }^{3}$

Nevertheless, Islam provides a rule, when a husband and wife can no longer continue marriage, in the sense of a mismatch of worldviews and domestic strife that cannot be reconciled, then there is an opportunity for divorce. Islam allows husband and wife to divorce, of course, for certain reasons, even though divorce is hated by Allah. ${ }^{4}$

Based on the divorce data of 20172018, the number of divorces in the Religious Courts in Indonesia varies. However, in the past three years, the Religious Courts in these three big cities have always occupied the highest number of divorce and divorce decisions, namely Surabaya, Bandung and Semarang. While the lowest number of divorce are in Ambon and Kupang.

Divorce is the termination of marriage between husband and wife,

${ }^{3}$ Moh. Idris Ramulyo, Hukum Pernikahan Islam (Jakarta: Bumi Aksara, 1996), 26-27.

${ }^{4}$ Muhammad Daud Ali, Hukum Islam dan Pandangan Agama, $2^{\text {nd }}$ Edition (Jakarta: PT. Raja Grafindo Persada, 2002), 102. 
with the husband's pledge before the Religious Court hearing. ${ }^{5}$ Based on the law, divorce can be carried out through a request for divorce based on the legally acceptable reasons.

The Qur'an calls on men and women not to be differentiated; they have the same responsibilities, rights and obligations. However, there is an impression of discrimination against women; for example, it is stated that the husband is one degree higher compared to the wife, and the husband is the leader. ${ }^{6}$ Women are considered not suitable to hold power. ${ }^{7}$ In divorce, the husband has absolute unilateral divorce rights. That is, without a clear reason even a husband may do polygamy without the wife's consent. ${ }^{8}$

Divorce suit (cerai gugat) is a wife's request to her husband to divorce or release herself from the marriage bond accompanied by iwadh (subtitution) in the form of money or goods to the husband on the wife's side in return for divorce. That is, in certain

\footnotetext{
${ }^{5}$ Ahrun Hoerudin, Pengadilan Agama,Bahasan Tentang Pengertian Pengajar Perkara dan Kewenangan Pengadilan Agama Setelah Berlakunya Undang-Undang No.7 Tahun 1989 Tentang Pengadilan Agama, (Jakarta: Citra Aditya Bakti, nd), 9.

${ }^{6}$ Khoirudin Nasution, Status Wanita di Asia Tenggara: Studi terhadap perundangundangan perkawinan muslim perkawinan kontemporer di Indonesia dan Malaysia, (Jakarta: INIS, 2002), 2.

${ }^{7}$ Asghar Ali Engineer, Hak-Hak Perempuan dalam Islam Mazhab, Trans. Farid Wajidi and Cici Farkha Assegraf, (Yogyakarta: LSSPA, 2000), 63.

${ }^{8}$ Ahmad Azhar Basyir, Hukum Perkawinan Islam, (Yogyakarta: Perpustakaan Fak. Hukum UII, 1995), 39.
}

situations wives who are tortured due to the act of their husbands have the right to demand divorce in exchange for something. ${ }^{9}$ Meanwhile, divorce (cerai talak) is believed to be the will of the husband and not the wife's initiative.

Based on the data, $70 \%$ of divorces are filed by the wife or divorce suit. The data from the Director General of Islamic Community Guidance of the Indonesian Ministry of Religion in 2018, from 2 million people who get married every year in Indonesia, 285,184 cases end in divorce annually in Indonesia. Therefore, it can be said that divorce trends in Indonesia are increasing from year to year. ${ }^{10}$

The factors that caused divorce in Indonesia range from the issue of infidelity, household disharmony, to economic problems. Economic occupied the most determinant factor of divorce, and $70 \%$ of wives who suit for divorce are due to the reason that the husband is unable to meet the economic needs of the family. So, what is exactly happened in Palu. This paper will analyze the background of divorce and its settlement in the Religious Court of Palu.

\section{Literature Review}

\subsection{Divorce from Islamic Perspective}

${ }^{9}$ Rahmat Hakim, Hukum Perkawinan Islam, $1^{\text {st }}$ Edition (Bandung: Pustaka Setia, 2000), 172.

${ }^{10 h t t p: / / m . k o m p a s i a n a . c o m / p o s t / e d u k ~}$ asi/2011/09/01/inilah-penyebab-perceraiantertinggi- di-indonesia/, Accessed 4 December 2018. 
In Islamic law, divorce is lawful but hated by Allah. According to Sayyid Sabiq, "divorce is a breaking of the bonds of marriage or dissolving marital relations". ${ }^{11}$ Divorce is divided into two, divorce and divorce suit. Divorce suit is defined as a divorce in which the husband was sued for divorce by the wife through the court, which then the court granted the lawsuit so that the relationship between the plaintiff (wife) and the defendant is terminated. ${ }^{12}$

In Islam, marriages that break up due to divorce are considered legal if pronounced immediately by the husband, but must still be done before the court. ${ }^{13}$ The aim is to protect all rights and obligations arising as a result of the divorce law.

\section{Divorce in the Regulation of Marriage} In the Law Number 1 of Year 1974 on Marriage, divorce is defined as A situation where a husband and a wife have had an inner mismatch that results in the breaking of a marriage bond through a court ruling. Regarding the issue of termination of marriage or divorce, it is regulated in Article 38 to Article 41 of the Marriage Law. ${ }^{14}$

11Sayyid Sabiq, Fiqih Sunnah II , 344.

12Zainnudin Ali, Hukum Perdata Islam Indonesia, (Palu: Yayasan Masyarakat Indonesi Baru, 2002), 906.

13 Rusli, R. (2013). The Role of Musalahah in Conflict Resolution: A Historical Perspective. Hunafa: Jurnal Studia Islamika, 10(2), 203-220.

14 Ibid, 908.
Article 38 states that marriages can be terminated because of death, divorce and due to court decisions. Marriage termination due to divorce is regulated in Article 39 to Article 41 of Marriage Law Number 1 of 1974 jo. Article 14 to Article 36 Government Regulation Number 9 of 1975. Article 39 of Act Number 1 of 1974 that stipulates that

1) Divorce can only be conducted before a court hearing, after the court has tried and failed to reconcile the two parties.

2) To divorce, there must be enough reasons, that between husband and wife will not be able to live in harmony as husband and wife.

3) The procedure for divorce before a court hearing is regulated in separate legislation. ${ }^{15}$

Thus, divorce can be ratified by the Religious Court, if it is conducted in front of the Religious Court, and has a number of reasons that are appropriate and in accordance with applicable laws and regulations. Meanwhile, Article 40 of Marriage Law Number 1 of 1974 stated:

1) The divorce suit is submitted to the court.

2) The procedure for filing the claim in Paragraph (1), and this article is regulated in separate legislation.

Furthermore, what is meant by a court as mentioned in article $1 \mathrm{sub} b$ Government Regulation No. 9 of Year 1975, is the Religious Courts for Muslims and the District Courts for non-Muslims.

${ }^{15}$ Law of Marriage Number 1 of the Year 1974, Article 39. 
In addition to the Marriage Law, Article 113 to Article 162 of the Compilation of Islamic Law (KHI) explains the causes of divorce, legal procedures and consequences. For example, Article 113 of the Compilation is the same as Article 38 of the Marriage Law, and Article 114 regarding marriages terminated by divorce, divorcc can occur if it is suited by the wife.

Article 115 of the Compilation of Islamic Law confirms the Article 39 of the Marriage Law in accordance with the concept of Compilation of Islamic Law, namely Muslims: "Divorce can only be carried out before the Religious Court hearing after the Religious Court fails to reconcile the two parties". 16

Although basically Islamic law does not stipulate that divorce must take place before a court hearing, because this provision is more beneficial to both parties, it is appropriate if Muslims are obliged to follow this provision. The court that has the authority to examine and decide on divorce is for Muslims is the Religious Courts, and for nonMuslims are in the District Court.

\section{Pillars and Conditions of Divorce}

The pillars of divorce include the husband, the wife, words of divorce (shigat talak) from the husband, and intentional (qasd). ${ }^{17}$ In Islamic law, for the validity of divorce, a husband who

\footnotetext{
${ }^{16}$ Kompilasi Hukum Islam, Article 113-115.

${ }^{17}$ Abd Rahman Ghazaly, Fiqh Munakahat. (Jakarta: Kencana, 2003), 201-204.
}

utters divorce is required to be rational, puberty, and in his own volition. ${ }^{18}$

Meanwhile, for the validity of divorce for wife, the conditions include:

a. The wife has been bound by a legal marriage with her husband. If the marriage agreement is doubtful, then the wife cannot be divorced by her husband.

b. The wife must be clean from menstruation, and has not been copulated by her husband during this clean period. ${ }^{19}$

Thus, it is clear that if one of the pillars and conditions above are not met, then the divorce dropped by the husband is considered invalid, because it does not bring any legal consequences.

\subsection{Religious Court}

A court is a place for resolving legal disputes that are carried out according to religious regulations. ${ }^{20}$ The religious court is one of the four legal judicial powers in Indonesia, that is a special because it hears certain cases related to civil law for Muslims. ${ }^{21}$ In Law Number 3 of 2006 on Religious Courts Article 1 paragraph (1) states that: Religious Courts are courts for people who are Muslim.

Religious Court as the court of first instance is the court that acts to receive, examine, and decide upon every request or claim at the earliest and

\footnotetext{
${ }^{18}$ Ibid.,

${ }^{19}$ Soemiyati, Hukum, 107.

${ }^{20} \mathrm{M}$ Idris Ramulyo, Beberapa Masalah tentang Hukum Acara Perdata Peradilan Agama, (Jakarta: Ind Hill Co, 1999), 12.

${ }^{21}$ Roihan A Rasyid, Hukum Acara Peradilan Agama (Jakarta: PT Raja Grafindo, 2000), 5.
} 
lowest stages. This is confirmed in Article 56 which reads:

The court may not refuse to examine and decide on a case that is subimitted on the reason that the law is not clear or unclear, but rather must examine it and must decide.

The authority of the Religious Court is to examine, decide upon, and settle cases at the first level between people who are Muslims in the fields of marriage, inheritance, testament, grants, endowments (waqf), and alms (sadaqah) based on Islamic law. ${ }^{22}$ In the case of inheritance, the authority of the Religious Court is to determine who can become an heir, property of inheritance, the portion of each heir, and the distribution of the inheritance..$^{23}$

\section{Methodology}

This study used a qualitative approach with the object of research is the Religious Court, Class 1 A in Palu. Thisis because the religious court in the city of Palu ranks highest in divorce cases in Central Sulawesi. Furthermore, the Religious Court, Class 1 A in Palu is also one of the legal institutions that has the authority to handle divorce cases among Muslim community in Palu.

Data were collected using observation techniques, in-depth interviews with officials in the Religious Court, and written documents. While

\footnotetext{
${ }^{22}$ Undang-Undang Nomor 7 Tahun 1989 Peradilan Agama Pasal 49.

${ }^{23}$ Abdullah Tri Wahyudi , Peradilan Agama di Indonesia, (Yogyakarta: Pustaka Pelajar Offset, 2004), 55.
}

the data analysis is done using reduction and verification techniques with various data sources. ${ }^{24},{ }^{25}$. The reduced data is then analyzed by claiming to the theoretical concepts used in this study. ${ }^{26}$

\section{Result and Discussion}

\subsection{Divorce Process in the Religious Court of Palu}

Based on the research in the field, it was obtained that the divorce process handled by the the Religious Court, Class 1, in Palu, can be described below:

1. In general, cases of divorce that were dealt with in the the Religious Court, Class $1 \mathrm{~A}$, in Palu include divorce initiated by husbad (cerai talak) and divorce initiated by wife (cerai gugat) with various reasons. ${ }^{27}$

2. Termination of divorce cases, both cerai talak and cerai gugat, is carried out after the party submits the application for divorce to the

24 Nurdin, N. (2017a). Research in Online Space: The Use of Social Media for Research Setting Jurnal Sistem Informasi (Journal of Information System), 13(1), 67-77.

25 Nurdin, N. (2017b). To Research Online or Not to Research Online: Using Internet-Based Research in Islamic Studies Context. Indonesian Journal of Islam and Muslim Societies, 7(1), 31-54.

26 Nurdin, N. (2016). The Roles of Information Technology in Islamic Bank Knowledge Management: A study of Two Syariah Banks in Palu. Hunafa: Jurnal Studia Islamika, 13(2), 181-217. https://doi.org/https://doi.org/10.24239/jsi.v1 3i2.444.181-217

${ }^{27}$ Khalis, Chairman of the Religious Court Class 1 A Palu, Interview, (22 November 2018). 
Religious Court of Palu verbally or in a written document. ${ }^{28}$

3. In order that the submission of divorce case is in accordance with the procedures and the law, both the plaintiff and the applicant can ask for help from the Religious Court regarding the procedure for making a claim or divorce application. In this case, the Religious Court provides assistance in accordance with applicable procedures. ${ }^{29}$

4. Legal aid services are available at the Religious Courts to the parties who are not aware of divorce procedures, called POSBAKUM with the officers that include lawyers, law graduates, and Sharia scholars who are members of advocate institutions or Legal Aid Institutions in higher education institutions. ${ }^{30}$

And this process has been in line with Talcot Parson's theory saying that, society is composed of a set of different subsystems based on their structure and functions on the wider community. When society changes, new subsystems are differentiated. ${ }^{31}$ Essentially, an essential aspect in the Parson evolutionary paradigm is the ability to

\footnotetext{
${ }^{28}$ Khalis, Chairman of the Religious Court Class 1 A Palu, Interview, (22 November 2018).

${ }^{29}$ Hadijah, Substitute Registrar, the Religious Court Class 1 A Palu, Interview, (24 November 2018).

${ }^{30}$ Rahmawati, Substitute Registrar, the Religious Court Class 1 A Palu, Interview, (24 November 2018).

${ }^{31}$ Rusli, R. (2018). Fikih Ekologi dan Kearifan Tradisional: Tinjauan Terhadap Konsep Ihya' al-Mawat dan Hima. Hunafa: Jurnal Studia Islamika, 5(3), 287-298.
}

adapt. His assumptions about changes make him considered a conservative theorist who tends to focus on the positive aspects of social change. ${ }^{32} \mathrm{He}$ considers that when the change occurs, the community generally grows with a better ability to overcome the problem.

\subsection{Causes of Divorce in Palu}

Based on the research in the Palu Religious Court Class $1 \mathrm{~A}$, the causes of divorce in Palu in 2018 include adultery, gamble, and others that causes disharmony in the household. As Khalis, the chairman of Religious Court of Palu, said:

Based on the divorce application letter that entered the Palu Religious Court, the factors causing the community to reuest the divorce varied greatly. We have classified it into several types of lawsuits or requests for divorce, among others, adultery, drunkenness, illicit behavior, gambling, and leaving one party. ${ }^{33}$

These factors have been classified by the the Religious Court Class $1 \mathrm{~A}$ of Palu as follows:

${ }^{32}$ Rusli, R. (2017). Wahdah Islamiyyah Palu: on Contemporary Islamic Legal Issues in The Internet. Hunafa: Jurnal Studia Islamika, 14(2).

${ }^{33}$ Khalis, Chairman of the Religious Court Class 1 A Palu, Interview (14 December 2018). 
Tabel: I

The Courses of Divorce in Palu city
\begin{tabular}{|l|l|l|l|l|l|l|}
\hline No & Months & Adultery & Drunk & Narcotics & $\begin{array}{c}\text { Gamb- } \\
\text { ling }\end{array}$ & $\begin{array}{c}\text { Leaving } \\
\text { Partners }\end{array}$ \\
\hline 01 & Januari & 0 & 1 & 0 & 0 & 20 \\
\hline 02 & Februari & 0 & 0 & 0 & 0 & 19 \\
\hline 03 & Maret & 0 & 1 & 0 & 0 & 21 \\
\hline 04 & April & 0 & 3 & 0 & 0 & 21 \\
\hline 05 & Mei & 0 & 4 & 0 & 0 & 14 \\
\hline 06 & Juni & 0 & 1 & 0 & 1 & 14 \\
\hline 07 & Juli & 0 & 0 & 2 & 1 & 19 \\
\hline 08 & Agustus & 0 & 0 & 1 & 1 & 12 \\
\hline 09 & September & 0 & 0 & 0 & 2 & 12 \\
\hline 10 & Oktober & 0 & 2 & 0 & 0 & 26 \\
\hline 11 & November & 1 & 0 & 0 & 0 & 19 \\
\hline 12 & Desember & 1 & 0 & 0 & 0 & 16 \\
\hline & Jumlah & 2 & 12 & 3 & 5 & 213 \\
\hline
\end{tabular}

Source: Annual report of religious court, 2018. ${ }^{29}$

From the table above, it can be said that there are five factors that cause divorce registered in the Religious Court Palu, that include adultery (2 cases), drunk (12 cases), dringking opium (3 cases), gambling (5 cases), and a husband leaving his wife (213 cases). Other factors were explained by the informants as follows: "The lawsuit and application for the divorce in Palu were also triggered by several factors including being sentenced to prison, polygamy, domestic violence, and bodily disability". ${ }^{34}$

On the other hand, the Religious Court, Class 1 A, Palu, also received delegations of appeals from the Palu Religious Court which also had to be legally processed by first appointing a set of judges to handle them properly. The appointed judge is given a task to carefully study the delegation case appealed before opening a trial to deal with the case. This has caused the judges and court clerks busy because they explore the incoming civil cases, hear

${ }^{34}$ Rusli, A Judge of the Religious Court of Palu Class 1 A, Interview (18 December 2018). them, and make the most appropriate decisions.

Based on the existing data that divorce occurs due to various social problems, among others, adultery, drunkenness, opium, gambling, and la husband leaving his hife or otherwise. These are social problem, and the Palu Religious Court Class 1 A has made the best effort in this regard. If the plaintiff and the defendant file a divorce suit in the Palu Religious Court Class 1 A, the Court provides a legal aid post (POSBAKUM) which aims to make the proceedings in the Religious Court run smoothly, and the court also always mediate each conflicting party, who litigate, so that all parties get justice in law. And this is in line with the structural functional theory of Talcot Parson who said that Parson put forward some functional requirements of a social system, namely

1) The social system must be structured (arranged) in such a way that it can operate in harmonious relations with other systems.

2) The social system must have the support of other social systems to maintain its continuity.

3) The social system must be able to meet the needs of its actors in a significant proportion.

4) The social system must be able to give birth to adequate participation from its members.

5) The social system must be able to control behavior that has the potential to interfere with its survival.

6) The social system requires language for its survival. 


\section{Conclusion}

From the discussion, it can be concluded that the divorce process handled by the Palu Religious Court consists of cerai gugat and cerai talak. Cerai gugat is a divorce filed by the wife against her husband before the court for reasons that comply with Islamic law and legal provisions. While cerai talak is a divorce submitted by a husband to his wife in front of the Religious Court.

Related to the causes of divorce in the City of Palu in the Palu Religious Court, from various divorce cases that entered the Palu Religious Court, the causal factors include adultery, drugs, liquor, polygamy, domestic violence, family disputes, forced marriages, apostasy, and factors the economy.

\section{REFERENCES}

Al-Qur'an dan Terjemahnya

Abud, Abdul Ghani. Keluargaku Surgaku: Makna Pernikahan, Cinta, Dan Kasih Sayang. Jakarta: Penerbit Hikmah, 2004.

Agoes, A.Y. Masalah-masalah dalam Perkawinan dan Keluarga dalam apa dan Bagaimana Mengatasi Problema Keluarga. Jakarta: Pustaka Antara 1996.

Ahmad Ramli. K. St, Pamoentjak. Kamus Kedokteran, Edition 24. Jakarta: Djambatan, 2000.

Al Hamdani, H.S.A. Trans. Agus Salim, Risalah Nikah. Jakarta: Pustaka Amani, 1989.

Ali, Mahfuz. Garis-Garis Besar Fiqh. Jakarta: Kencana, 2003.
Ali, Mohammad Daud. Hukum Islam dan Peradilan Agama. Jakarta: Raja Grafindo Persada, 1997.

Ali, Muhammad Daud. Hukum Islam dan Pandangan Agama, Cet. 2. Jakarta: PT. Raja Grafindo Persada, 2002.

Ali, Zainudin. Hukum Perdata Islam Indonesia. Palu: Yayasan Masyarakat Indonesi Baru, 2002.

Anwar, Yesmil dan Adang. Pengantar Sosiologi Hukum. Jakarta: PT Gramedia Widiasara Indonesia, 2008.

Ari, Donal et al. Intrroduction to research, Trans. Arief Rahman, Pengantar Penelitian dan Pendidikan. Surabaya: Usaha Nasional, t.th.

Arifin, Imron. Penelitian Kualitatif dalam Ilmu-ilmu Sosial dan Keagamaan, $10^{\text {th }}$ Edition. Bandung: Remaja Rosda Karya, 1999.

Arikunto, Suharsimi. Manajemen Penelitian. Jakarta: Rineka Cipta, 2005.

Awangga, Surya Putra N. Desain Proposal Penelitian, Cet. 1. Yogyakarta: Pyramid Publisher, 2007.

Az-Zuhaili, Wahbah. Fiqih Islam wa Adillatuhu, Vol. 4. Jakarta; Gema Insani, 2011.

Bahari, Adib. Prosedur Gugatan Cerai dan Pembagian Harta Gono-Gini dan Hak Asuh Anak. Yogyakarta: Pustaka Yustisia, 2012.

Basyir, Ahmad Azhar. Hukum Perkawinan Islam. Yogyakarta: Perpustakaan Fak. Hukum UII, 1995. 
Bombang, Saifullah. Hakikat Keadilan dalam Poligami (sebuah Kajian Hukum Islam). Unpublished Dissertaiton. Makassar: Universitas Hasanuddin.

Bungin, Burhan. Analisis Data Penelitian kualitatif, 2nd Edition. Jakarta: Raja Grafindo, 2003.

C. Robert \& Stern J. Tailor, Kualitatif, Dasar-dasar Penelitian. Surabaya: Usaha Nasional, 1993.

Chaplin, JP. Kamus Lengkap Biologi, Terj.Kartini Kartono. Jakarta: PT Raja Grafindo Perasada, 2004.

Dagun, Save M. Psikologi Keluarga. Jakarta, Rineka Cipta, 1990.

Damardi, Hamid. Metode Penelitian Pendidikan, 2nd Edition. Bandung: Alfabeta, 2011.

Daradjat, Zakiah. Peranan Agama dalam Kesehatan Mental. Jakarta: Gunung Agung, 1998.

Daud Ali, Muhammad. Hukum Islam dan Peradilan Agama. Jakarta: PT. Raja Grafindo Persada, 2002.

Departemen Agama RI. Al-Qur'an dan Terjemahnya. Semarang : PT. Karya Toha Putra, 1999.

Departemen Agama RI. Al-Qur'an dan Terjemahnya. Semarang : PT. Karya Toha Putra, 1999.

Departemen Pendidikan Nasional. Kamus Besar Bahasa Indonesia, Edisi VI, $5^{\text {th }}$ Edition. Jakarta: Balai Pustaka, 2008.

Djalil, A. Basiq. Peradilan Agama DI Indonesia, $1^{\text {st }}$ Edition. Jakarta: Prenada Media Group, 2006.

Engineer, Asghar Ali. Hak-Hak Perempuan dalam Islam Mazhab, Trans. Farid Wajidi dan
Cici Farkha Assegraf. Yogyakarta: LSSPA, 2000.

Fiorina, Carly. Karena Seks Ingin Dimengerti. Yogyakarta: Gita Media, 2008.

Ghazaly, Abd Rahman. Figh Munakahat. Jakarta: Kencana, 2003.

Gunarsih, D.S Hak dan Kewajiban Suami Istri. Surabaya: Bina Ilmu,1993.

Haerudin, Ahrun. Pengadilan Agama,Bahasan Tentang Pengertian Pengajar Perkara dan Kewenangan Pengadilan Agama Setelah Berlakunya Undang -Undang No.7 Tahun 1989Tentang Pengadilan Agama. Jakarta: Citra Aditya Bakti, tt.

Hakim, Rahmat. Hukum Perkawinan Islam, $1^{\text {st }}$ Edition. Bandung: Pustaka Setia, 2000.

Hassan, A. Terjemah Bulughul Maram. Bandung, Diponegoro, 2006.

Hukum Oline, Melihat Tren Perceraian dan Dominasi Penyebabnya (online)

(https://www.hukumonli $\underline{\text { ne.com/berita/baca/lt5b1fb923c }}$ b04f/melihat-tren-perceraiandan-dominasi-penyebabnya/), diakses tanggal 8 April 2019.

Idris Ramulyo, Mohammad. Hukum Perkawinan Islam. Jakarta: Bumi Aksara, 1996.

Indiarti, M.T. Kalender Seksual Anda. Yogyakarta: El Matera Publising, 2007.

Kasiram, Moh. Strategi Penelitian Tesis Program Magister By Research. Malang: Pascasarjana, 2002. 
Kinloch, Graham C. Perkembangan dan Paradigma Utama Teori Sosiologi. Bandung: Pustaka Setia, 2009.

Low, Lyne. Memahami Seks. Jakarta: Gaya Favorit Press, 2006.

M Azzam, Abdul Aziz. \& Hawwas, Abdul Wahhab Sayyed. Figh Munakahat (Khitbah, Nikah, dan Talak). Jakarta: Amzah, 2009.

M. Zein, Satria Effendi. Problematika Hukum Keluarga Kontemporer Analisis Yurisprudensi dengan Pendekatan Ushuliyah, $1^{\text {st }}$ Edition, Jakarta: Kencana Prenada Media Group, 2004.

Mahkamah Agung-Badilag. Pedoman Pelaksaan Tugas dan Administrasi Peradilan Agama: Buku II, MA-RI. Jakarta: Badilag, 2011.

Makarao, Moh. Taufik. Pokok-pokok Hukum Acara Perdata. Jakarta: Rineka Cipta, 2004.

Mardani. Hukum Acara Perdata Peradilan Agama \& Mahkamah Syar'iyah, $2^{\text {nd }}$ Edition. Jakarta: Sinar Grafika, 2010.

Margono, S. Metode Penelitian Pendidikan, $2^{\text {nd }}$ Edition. Jakarta: Rineka Cipta, 2000.

Maria. Jika Benturan Melanda Perkawinan dalam Nasehat Perkawinan dan Keluarga. Jakarta: BP4, 1998.

Metokusumo, Sudikno. Hukum Acara Perdata Indonesia. Bandung: Liberty, 1993.

Milles, A Mattew B. Michael Huberman. Qualitative Data Analisis, $1^{\text {st }}$ Edition. Jakarta: UI-Press, 1992.

Moleong, Lexy J. Metodologi Penelitian Kualitatif, 29th Edition. Bandung: Remaja Rosdakarya, 2011.
Mughniyah, Muhammad Jawad. Fiqih Lima Maddzhab Ja"fari, Hanafi, Maliki, Safi"i, Hambali, Jakarta: Lentera, 25th Edition, 2010.

Mughniyah, Muhammad Jawad. Terjemahan Al-Fiqh 'Ala AlMadzahib Al- Khamsah.

Bandung: Pustaka Alkautsar, 2009.

Mukhtar, Kamal. Asas-Asas Hukum Islam Tentang Perkawinan, 2rd Edition. Jakarta: Bulan Bintang, 1993.

Mustafa, Fahmi. Kesehatan Jiwa Dalam Keluarga, Sekolah dan Masyarakat. Terj. Zakiah Dardjat. Jakarta: Bulan Bintang, 1997.

Naqiyah, Rukmana. Tuntunan Praktis Perkawinan. Jakarta: Penebar Swadaya 2007.

Nasution, Khoirudin. Status Wanita di Asia Tenggara: Studi terhadap perundangundangan perkawinan muslim perkawinan kontemporer di I ndonesia dan Malaysia. Jakarta: INIS, 2002.

Nasution. Metode Research. Jakarta: Bumi Aksara, 2009.

Nurdin, N. (2016). The Roles of Information Technology in Islamic Bank Knowledge Management: A study of Two Syariah Banks in Palu. Hunafa: Jurnal Studia Islamika, 13(2), 181217.

https://doi.org/https:/ / doi.org/ 10.24239/jsi.v13i2.444.181-217

Nurdin, N. (2017a). Research in Online Space: The Use of Social Media for Research Setting Jurnal Sistem 
Informasi (Journal of Information System), 13(1), 67-77.

Nurdin, N. (2017b). To Research Online or Not to Research Online: Using Internet-Based Research in Islamic Studies Context. Indonesian Journal of Islam and Muslim Societies, 7(1), 31-54.

Nuruddin, Amir dan Azhari Akmal Tarigan. Hukum Perdata Islam Di Indonesia: Studi Kritis Perkmbangan Hukum Islam Dari Fikih, UU No. 1/1974 Sampai KHI. Jakarta: Kencana 2006.

Peraturan Pemerintah Nomor 9 Tahun 1975 (Pasal 19)

Ramulyo, M Idris. Beberapa Masalah tentang Hukum Acara Perdata Peradilan Agama. Jakarta: Ind Hill Co, 1999.

Ramulyo, Moh. Idris. Hukum Pernikahan Islam. Jakarta: Bumi Aksara, 1996.

Rasyid, Roihan A. Hukum Acara Peradilan Agama. Jakarta: PT Raja Grafindo, 2000.

Rusli, R. (2018). Fikih Ekologi dan Kearifan Tradisional: Tinjauan Terhadap Konsep Ihya' al-Mawat dan Hima. Hunafa: Jurnal Studia Islamika, 5(3), 287-298.

Rusli, R. (2013). The Role of Musalahah in Conflict Resolution: A Historical Perspective. Hunafa: Jurnal Studia Islamika, 10(2), 203220.

Rusli, R. (2017). Wahdah Islamiyyah Palu: on Contemporary Islamic Legal Issues in The Internet. Hunafa: Jurnal Studia Islamika, 14(2).
Sa'adah, Marzuki Umar. Perilaku Seks Menyimpang dan Seksualitas. Yogyakarta: UII Press, 2001.

Sabiq, Syayid. Fikih Sunnah 8, diterjemahkan Muhammad Thalib, "Fikih Sunnah". Bandung: PT Al-ma'arif, 1980.

Saidan, Muhammad. Analisis FaktorFaktor Penyebab Terjadinya Perceraian Di Pemkot Tahun 2013-2014. Surakarta: Universitas Muhammadiyah Surakarta, 2014.

Salim Bin 'Ied Al-Hilali, Syaikh. Ensiklopedia Larangan, Vol 3. Bogor; Pustaka Imam Syafi'i, 2005.

Santoso, Tri Wibowo Budi. Teori Sosiologi Modern. Jakarta: Kencana Prenada Media Group, 2007.

Sarwono, Sarlito Wirawan . Menuju Keluarga Bahagia 2. Jakarta: Bhatara Karya Aksara, 1982.

Soebekti, Wienarsih Imam dan Sri Soesilowati Mahdi. Hukum Perorangan dan Kekeluargaan Perdata Barat. Jakarta :Gitama Jaya Jakarta, 2005.

Soemiyati. Hukum Perkawinan Islam dan Undang-undang Perkawinan. Yogyakarta: Cetakan Keenam, Liberty, 2007.

Soetantio, Retnowulan. Hukum Acara Perdata dalam Teori dan Praktek. Bandung: Mandar Maju, 1997.

Sudarshono. Perceraian dalam Masyarakat dan Pencegahannya. Jakarta: Gramedia 1999.

Sudarsono. Hukum Perkawinan Nasional. Jakarta : PT Rineka Cipta, 1991. 
Sudrajat, M. Subana. Dasar-dasar Penelitian Ilmiah, $1^{\text {st }}$ Edition. Bandung: Pustaka Setia, 2001.

Sugiyono. Metode Penelitian Kuantitatif, Kualitatif, dan $R \in \mathcal{E} D, 14^{\text {th }}$ Edition. Bandung: Alfabeta, 2011.

Sugiyono. Metode Penelitian Pendidikan pendekatan kuantitatif, kualitatif, dan REd. Bandung: Alfabeta, 2012.

Suhartono, Irawan. Metode Penelitian Sosial, $5^{\text {th }}$ Edition. Bandung: Remaja Rosdakarya, 2002.

Surahman, Wirahmat. Pengantar Penelitian Ilmiah, Cet. 8. Bandung: Tarsito, 1998.

Syaifudin, Muhammad. Hukum Perceraian. Palembang: Sinar Gravika, 2012.

Syarifuddin, Amir. Hukum Perkawinan Islam di Indonesia: Antara Figh Munakahat Dan UndangUndang Perkawinan. Jakarta: Kencana 2006.

Tri Wahyudi, Abdullah. Peradilan Agama di Indonesia. Yogyakarta: Pustaka Pelajar Offset, 2004.

Umar, Husein. Metode Penelitian untuk skripsi dan Tesis Bisnis, $4^{\text {th }}$ Edition. Jakarta: Raja Grafindo, 2001.

Undang - Undang Nomor 7 Tahun 1989 Peradilan Agama Pasal 49.

Undang-undang No 1 tahun 1974 tentang Perkawinan Bab 2 pasal 7 ayat 1.

Undang-Undang Nomor 3 Tahun 2006 dan Undang-Undang Nomor 50 Tahun 2009.
Undang-undang Perkawinan No. 1 Tahun 1974 tentang Perkawinan.

Wardah, Cece. Peradilan Agama (online) http:// wardah cheche. blogspot. com/2014/04 /peradilan- agama .html), Accessed 7 Desember 2018.

Widodo. Faktor-faktor Serta Alasan yang Menyebabkan Tingginya Angka Cerai Gugat, Jurnal Hukum, Universitas Surakarta, 2013.

Wiramiharja, A. Sutarto. Psikologi Abnormal. Bandung: Refika Aditama, 2005.

Yin, Robert K.Case Study Design and Methods, diterjemahkan oleh M. Djauzi Mudzakir dengan judul: Studi Kasus Desain dan Metode, $1^{\text {st }}$ Edition. Jakarta: PT.Raja Grafindo Persada, 2002.

Zarkasyi, Muchtar. Sejarah Peradilan Agama di Indonesia, Makalah Materi Pendidikan Calon Hakim Angkatan III Mahkamah Agung RI Tahun 2008.

Zuhriah, Erfaniah. Peradilan Agama Di Indonesia (Sejarah Pemikiran dan Realita), $2^{\text {nd }}$ Edition, Malang: UIN Malang Press, 2009 